\title{
May Deficiency of Catecholamine Catabolizer Renalase be the Underlying Primary Reason of Autism?
}

\author{
Suleyman Aydin*
}

Department of Medical Biochemistry (Firat Hormones Research Group), School of Medicine, Firat University, Elazig, Turkey

${ }^{*}$ Corresponding author: Prof. Dr. Suleyman Aydin, Department of Medical Biochemistry (Firat Hormones Research Group), School of Medicine, Firat University, 23119-Elazig, Turkey, Tel: 905334934643, Fax: 904242379138; E-mail: aydin1@hotmail.com

Received date: January 15, 2018; Accepted date: January 17, 2018; Published date: January 24, 2018

Citation: Aydin S (2018) May Deficiency of Catecholamine Catabolizer Renalase be the Underlying Primary Reason of Autism? J Clin Mol Endocrinol 3:1.

Copyright: (C) 2018 Aydin S. This is an open-access article distributed under the terms of the Creative Commons Attribution License, which permits unrestricted use, distribution, and reproduction in any medium, provided the original author and source are credited.

\section{Editorial}

Autism disease is biochemically characterized with the increase of norepinephrine which is among the members of catecholamines. Renalase enzyme is responsible for metabolization of catecholamines including epinephrine. If there is not enough renalase enzyme, it causes a set of pathologies such as autism since catecholamines cannot be extinguished at appropriate period of time [1]. Accordingly we tried to hypothesize the possible relationship of autism disease with renalase enzyme for the first time in this editorial and we laid emphasis on the fact that renalase might be a new agent for the treatment and diagnosis of autism disease.

Autism is a development disorder in which the patient is alone with his/her inner world (social communication, interaction and behavior disorder). Autism develops natally and it has a genetical transition background, a complicated neurobiological basis and it generally arises before 3 ages [2,3]. Due to American Ministry of Health data, 1 of 88 children in school age is diagnosed as autism [2]. Autism is observed 3-4 fold more in boys than girls [2,3]. Even though major improvements are recorded about autism, underlying biochemical mechanisms cannot completely enlighten yet.

In biochemical investigations which are executed in order to reveal the underlying reasons of autism, increased level of norepinephrine is detected in autism patients and their relative's blood and low level of dopamine beta-hydroxylase activity is notified [4]. These findings demonstrate the hyperfunction of noradrenergic system in autistic patients. Other clues indicating the hyper-functional of noradrenergic system in these patients are occurrence of cardiovascular abnormalities-in other words high rate of pulse and high blood pressure in autistic children [5].

When we select the aforementioned findings as a baseline, we hypothesize in this editorial that high norepinephrine levels and high blood pressure may be related to inadequacy of catecholamine catabolizing renalase enzyme in autistic patients. Dopamine, epinephrine and norepinephrine molecules are known as catecholamines [6]. Renelase enzyme which is a flavine/adenine/dinucleotide dependent amine oxidase, extinguish these cathecolamines by converting epinephrine and norepinephrine to 3-methoxy-4-hydroxymandelic acid (VMA) and dopamine to homovanilic acid [7]. Renalase enzyme was discovered in kidney tissue in 2005 for the first time [7] and it was notified to be synthesized in various biological tissues including heart, liver and brain [8,9]. Normal level of renalase enzyme in circulatory system is stated to range within $3-5 \mu \mathrm{g} / \mathrm{ml}$ [8]. It can be concluded that lower and higher levels out of this range may cause a pathological situation. Renal levels in circulation may decrease in autism patients. Renalase level is strictly detected by at least three factors such as renal function, renal perfusion and cathecolamines. If the primary renalase synthesizer organ kidneys lose their function, a decrease in renalase levels takes place $[7,9]$. Decrease in renalase levels causes a rise in blood pressure by causing the high rate of cathecolamines in the circulation. As it can be remembered that high rate of blood pressure may originate from inadequate releasing of renalase from biological tissues including kidneys. We should remind that noradregenic (and adregenic) cells locate at locus caeruleus and pons [10]. Axones of these neurons are projected to cerebral cortex, limbic system, thalamus and hypothalamus with median forebrain bunches [10]. We also know that common developmental disorders (CDD) (including autism) are related to cathecolamine levels. In this case, quantities of cathecolamine levels in brain have bigger pathological importance than the quantity of cathecolamines in circulation. Renalase cannot pass blood-brain barrier because it is a $3.8 \mathrm{kDa}$ big molecule [8]. Accordingly, renalase levels synthesized in brain as a result of the degradation of cathecolamines are related to renalase amount. Epinephrine is observed in high concentrations in case of autism [4]. This means that epinephrine catabolition may be less or inadequate because of inadequate synthesis of renalase in brain parts because of an atrophy. Epinephrine levels may be high in autism patients for this reason. This kind of patients may have a resistance to renalase enzyme and they may have a problem in catabolizing cathecolamines because of this. But no matter what the reason is, epinephrine reducing drugs in brain or increasing the activity of renalase enzyme seems like a new treatment approach in autism patients. In addition, investigating the levels of cathecolamine and renalase in autistic individuals will help diagnosis and will provide data for researching the treatment 
options. There are promising results in autistic children with imipramine which is a tricyclic compound hindering reverse oscillation of norepinephrine and 5HT and with methysergidewhich is a non-selective 5HT antagonist [11]. Renalase enzyme seems like an agent with a potential of being an alternative option in autism patients.

\section{References}

1. Allely CS, Wilson P (2011) Diagnosing autism spectrum disorders in primary care. Practitioner 255: 27-30.

2. Baio J (2012) Prevalence of autism spectrum disorders-Autism and Developmental Disabilities Monitoring Network, 14 sites, United States, 2008. MMWR Surveillance Summaries 61: 1-19.

3. Lami F, Egberts K, Ure A, Conroy R, Williams K (2017) Measurement properties of instruments that assess participation in young people with autism spectrum disorder: A systematic review. Dev Med Child Neurol.

4. Lake CR, Ziegler MG, Murphy DL (1977) Increased norepinephrine levels and decreased dopamine-beta-hydroxylase activity in primary autism. Arch Gen Psychiatry 34: 553-556.

5. Kleberg JL, Thorup E, Falck-Ytter T (2017) Visual orienting in children with autism: Hyper-responsiveness to human eyes presented after a brief alerting audio-signal, but hyporesponsiveness to eyes presented without sound. Autism Res 10: $246-250$

6. Swartz SR, Moberg GP (1986) Effects of epinephrine, norepinephrine, and dopamine on gonadotropin-releasing hormone-induced secretion of luteinizing hormone in vitro. Endocrinology 118: 2425-2431.

7. Xu J, Li G, Wang P, Velazquez H, Yao X, et al. (2005) Renalase is a novel, soluble monoamine oxidase that regulates cardiac function and blood pressure. J Clin Invest 115: 1275-1280.

8. Aydin S, Ugur K, Aydin S (2017) Could pulmonary hypertension be the cause of renalase insufficiency? J Metab 1: 2.

9. Aydin S, Aydin S (2017) Can strict control of renalase present a new treatment alternative in regulating blood pressure?. J Cardiovasc Med Cardiol 4: 008-009.

10. Mejías-Aponte CA, Drouin C, Aston-Jones G (2009) Adrenergic and noradrenergic innervation of the midbrain ventral tegmental area and retrorubralfield: Prominent inputs from medullary homeostatic centers. J Neurosci 29: 3613-3626.

11. Dryden S, Wang Q, Frankish HM, Pickavance L, Williams G (1995) The serotonin (5-HT) antagonist methysergide increases neuropeptide $\mathrm{Y}$ (NPY) synthesis and secretion in the hypothalamus of the rat. Brain Res 699: 12-18. 